\title{
Julia Strauss, State Formation in China and Taiwan: Bureaucracy, Campaign, and Performance
}

(New York, NY: Cambridge University Press, 2019), 292p. \$84.99 hardback, \$25.99 paperback

\section{Carl Minzner ${ }^{1}$}

Accepted: 29 March 2021 / Published online: 6 April 2021

(c) Journal of Chinese Political Science/Association of Chinese Political Studies 2021

If you want to understand why Beijing and Taipei have both been successful at controlling the coronavirus epidemic - as well as the roots of their vastly different approaches-read this book.

To the casual reader, this might seem misplaced. After all, Strauss' excellently researched and well-written work is on the surface a narrow comparison of politics, bureaucracy, land reform and political terror in the late 1940s and early 1950s in the People's Republic of China (China) and the Republic of China (Taiwan).

However, her book is a much deeper look into the process of state formation. She expertly analyzes how the two competing regimes that arose from the decades-long Chinese civil war successfully built effective systems of control in newly occupied territories on opposite sides of the Taiwan Straits - namely, the Sunan region around Shanghai (for the Chinese Communist Party, CCP), and on the former Japanese colony of Taiwan (for the Nationalist Party, KMT).

Her short answer is bureaucracy. Her longer answer is that both regimes shared a focus on developing effective formal, hierarchical personnel structures for Party cadres and state managers, governed by "two overlapping modalities of state building and policy implementation: (1) the bureaucratic and (2) the campaign." And she illustrates how both regimes resorted to an alternating mix of those policies in their respective land reform and political suppression policies.

Crucially, Strauss also demonstrates their differences. For if the CCP and KMT belonged to the same broad family of Leninist authoritarian regimes, key genetic differences had already begun to emerge at this early stage of their separation from each other. Early CCP campaigns heavily emphasized bottom-up popular participation, accompanied by colorful propaganda aimed at awakening the masses to participate in public denunciations or beatings of designated targets.

Carl Minzner

cminzner@law.fordham.edu

1 Fordham Law School, New York, NY, USA 
In contrast, their ROC counterparts were strongly top-down and bureaucratic in nature, clothed in legalistic language, with death sentences handed down in closed-door political trials announced in staid black-and-white newspaper articles, with no effort at mass mobilization.

Naturally, this presages subsequent shifts. In Taiwan, campaigns steadily faded into the background of the KMT police state bureaucracy of the 1960s and 1970s. In contrast, China saw the use of campaigns widen, routinize, and expand - until they swallowed the CCP's own bureaucratic apparatus itself entirely in the chaos of the Cultural Revolution.

Unfortunately, reviews that only praise a book tend not to be taken seriously, and Strauss' work deserves attention. Consequently, it is worth concluding with at least one critical suggestion.

Strauss explicitly focuses on the 1949-54 period, precisely because that is when both the CCP and KMT regimes were simultaneously struggling to establish state control over society. Her comparative terror statistics focus on 1949 to 1954 , while the chapter on land reform notes: "Even now there is substantial agreement in the literature that land reform in Taiwan was both uniquely progressive and devoid of violence: in the words of one scholar, 'throughout the reform period of 1949 to 1953, there was not a single known instance of violence."”.

That choice leaves a crucial date just outside her comparative focus: 1947. For Sunan and Taiwan are not exactly the same. In 1949, the CCP was only just beginning to struggle to establish its rule in recently conquered Sunan. In contrast, the KMT was not only already several years into its control over Taiwan - it had also already liquidated tens of thousands of Taiwanese intellectuals and political opponents in an orgy of state-sponsored violence following the islandwide protest movement against KMT rule in February 1947.

In short, while the CCP in 1949-54 was dependent on regular application of violence through its early 1950s political campaigns in Sunan to instill a level of fear among citizens at large, the KMT was already ruling over a society thoroughly shaken and terrorized by mass executions.

While this reviewer fully agrees with Strauss' argument regarding the differences between CCP and KMT rule, it is worth underlining the fact that the subsequent top-down, legalistic, bureaucratic KMT rule in Taiwan was in fact explicitly founded on an exceptionally violent episode that cowed society in much the same manner as decades of bottom-up CCP-led campaigns did in the PRC.

Overall, an excellent book, well worth the attention that it will receive from both historians of modern China and political scientists interested in state formation.

But the value of Strauss' work is far, far greater, extending well beyond academia. Indeed, her analysis explains contemporary issues that were not remotely on anyone's radar screen when published in 2019.

What's behind the effective response by Beijing and Taipei to the epidemic that paralyzed the rest of the world? Why was Taipei able to implement-nearly overnight-a bloodless, effective, top-down technocratic response? Why was Beijing able to launch a "people's war" on the virus marked by mass mobilization of state and society alike? Why did each not adopt the approach adopted by 
the other? Strauss has her finger on the core issue: specific bureaucratic capacities and modalities of response that were hardwired into the political systems of both China and Taiwan at an early stage of their development, and that have been honed and practiced in the decades since.

The past as prologue, in both Taipei and Beijing. Scholars tend to avoid spiking the football when their research scores a touchdown. But after nailing the core global issue of 2020, Strauss should start the tradition.

Professor Carl Minzner specializes in Chinese law and politics. He is the author of End of an Era: How China's Authoritarian Revival is Undermining Its Rise (Oxford University Press, 2018). 